\title{
THE ESTIMATION OF THE GROUNDWATER STORAGE AND ITS DISTRIBUTION IN UZBEKISTAN
}

\author{
Sri Wahyuni ${ }^{1}$, Satoru OISHI ${ }^{2}$ and Kengo SUNADA ${ }^{3}$ \\ ${ }^{1}$ Student member of JSCE, PhD student, University of Yamanashi (4-3-11, Takeda, Kofu, Yamanashi 400-8511, \\ Japan) \\ ${ }^{2}$ Member of JSCE, Dr. of Eng., Associate Professor, University of Yamanashi (4-3-11, Takeda, Kofu, Yamanashi \\ 400-8511, Japan) \\ ${ }^{3}$ Fellow of JSCE, Dr. of Eng., Professor, University of Yamanashi (4-3-11, Takeda, Kofu, Yamanashi 400-8511, \\ Japan)
}

\begin{abstract}
This paper provided reasonable results of groundwater storage estimation and its distribution on each aquifer in Uzbekistan. The largest aquifer was Kyzylkum. There were very rare publication and discussion paper on the groundwater storage in arid region. Then the results were useful finding to support the decision maker and researchers who were interested in this subject. In this study, the estimation of groundwater storage using GIS techniques and utilization of borehole data was proposed. The result showed that groundwater storage in Uzbekistan was about 15.5 BCM (billion cubic meters), while in Kyzylkum aquifer was about 6.8 BCM. Compared with the result from Central Asia Water Info, field survey and roundtable discussion Uzbekistan on August 2007, the results was verified, reliable and acceptable.
\end{abstract}

Key Words: groundwater storage, arid region, Kyzylkum, borehole data, GIS techniques

\section{INTRODUCTION}

Groundwater is the main source to fulfill the water demand in Uzbekistan because this country is a landlocked country in Central Asia. The total area of Uzbekistan is $447,400 \mathrm{~km}^{2}$. Sustainability of groundwater storage in this country is very important due to high demand of groundwater. The resource can be optimally used and sustained only if the quantity and quality of groundwater is assessed. Since several years ago, many researchers such as Veselov et al. ${ }^{1)}$ and Takhirov et al. ${ }^{2)}$ did research on the availability of groundwater in this region. But they did not estimate the groundwater storage. The exploitation of groundwater is very high risk without knowing the storage. They will extract it as much as possible they need. It is essential to maintain a proper balance between the groundwater quantity and its exploitation ${ }^{3)}$.

Zavialov $^{4)}$ stated that the water budget component in Aral Sea Basin (including Uzbekistan) was very few number of estimation had been made. Dukhovny and Schutter ${ }^{5)}$ studied the groundwater storage in Aral Sea Basin including Uzbekistan. But the result was not providing the detail explanation about groundwater storage in each aquifer and its distribution. Regarding with roundtable meeting in ICARDA (International Center for Agriculture Research in the Dry Areas) Uzbekistan on August $23^{\text {rd }} 2007^{6}$, the groundwater storage in Uzbekistan has been estimated by conventional method. However the result was not published to international community. Here, GIS technique was not being applied yet to estimate the groundwater storage. The conventional approaches for groundwater investigation were based on the ground surveys and the exploratory of the drilling tests. They were time consuming and uneconomical.

Johnson and Njuguna ${ }^{7)}$, found that GIS technique was good tools to determine the storage capacity of the Central and West Coast basin aquifers in Los Angeles, California. Other researchers, Singh and Prakash ${ }^{8)}$ were using GIS to evaluate the potential groundwater in India, 2002, and also they found that GIS technique had capability to find out the potential zones of groundwater.

The distribution of groundwater storage in each aquifer was required to control the groundwater extraction. For example, in the Kyzylkum area, the annual precipitation was limited ranging from 100- 
$200 \mathrm{~mm}$. There was no river system available also. Since the main source of water was coming from the groundwater, then the quantity of groundwater was necessary to be determined.

The present study attempted to overcome lack of information about the groundwater storage on this area and to provide the acceptable results of the estimated distribution of groundwater storage. The detail mapping and explanation of the groundwater storage for each aquifer was the originality and the most important finding of this study.

\section{STUDY AREA}

In Fig.1, the area of study showed that aquifer (pink color) was lying in Uzbekistan and Kazakhstan. Here, it was obviously seen that boundary of groundwater was trans-boundary between these two countries. To estimate the groundwater storage in Uzbekistan, the whole area of aquifers should be considered first, then the specific area could be determined.

The detail map of boundary of aquifer (Fig.2) showed that from the north to the west, the area of study was bounded by Sultanuizdak fault. From the west to the south, it was bounded by Bukantau fault while the eastern part was bounded by the ridge of Karatau. In the northern part, it was bounded by the Aral Sea. Detail of A-A' cross section of geohydrology profile showed in Fig. 3.

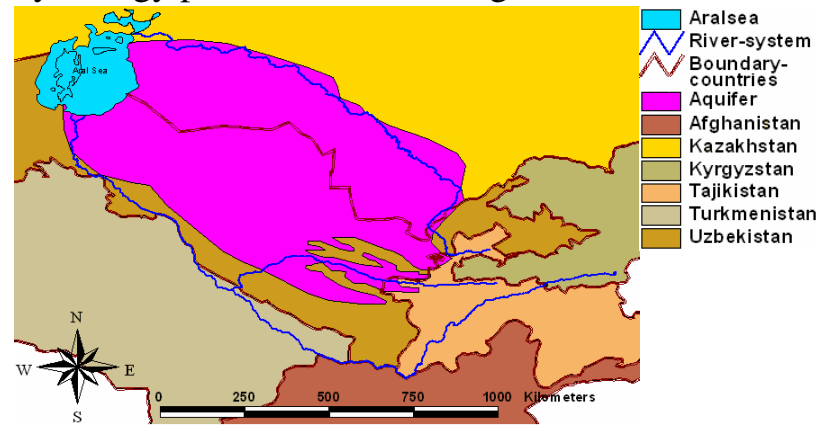

Fig.1 Map showing the location of aquifer in the area study.

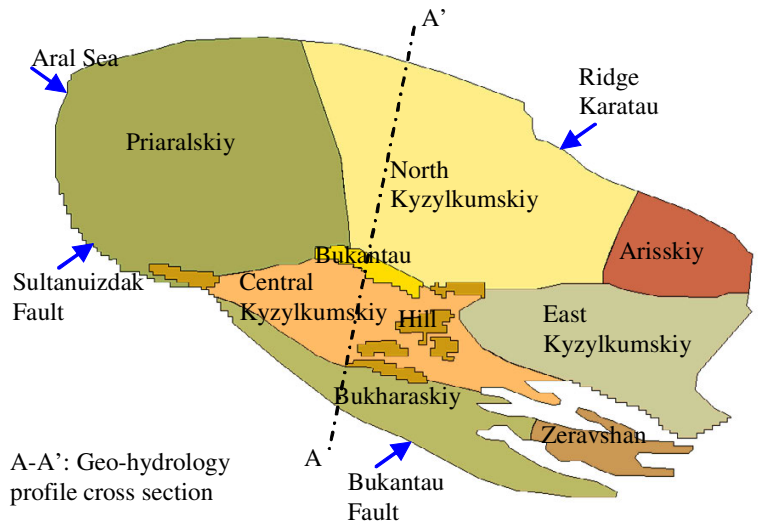

Fig.2 Aquifer names and boundaries.
The Priaralsky aquifer, The North Kyzylkumsky aquifer and The East Kyzylkumsky aquifer were lying between two countries, while The Arissky aquifer was located on Kazakhstan only. This kind of boundaries was used in this calculation as well as used by Veselov et al. ${ }^{1)}$ and Takhirov et al. ${ }^{2)}$.

\section{DATA AND METHODOLOGY}

\section{(1) Required data}

As previously stated in the introduction, the detail data of this study area was limited. In this study, data were taken from the global data and being verified with the field survey. The main data needed was geo-hydrology map. It was used to determine boundary of aquifer and surface area aquifer. The borehole data was used to estimate the thickness of aquifer. Another data was the specific yield of each aquifer.

\section{a) Geo-hydrology map}

The boundary of aquifer was determined with the geo-hydrology map compiled from Veselov et al. ${ }^{1)}$ and Takhirov et al. ${ }^{2)}$.

\section{b) Borehole data}

There were 73 borehole locations in the study area ${ }^{1)}$. Veselov et al. studied the groundwater in Eastern Priaralye. They studied the groundwater flow and salinity of groundwater in Aral Sea basin including Uzbekistan. Since they did not study the groundwater storage, in this study the borehole data was used to determine aquifer depth.

Fig. $3^{1)}$ showed the schematic figure of geohydrological profile from borehole data, where the depth of layer on the northern part (right side) was deeper than the layer on the southern part (left side).

Regarding to the geology condition, the area of study was divided into 12 layers. Determination of its layer was based on the sediment deposition time.

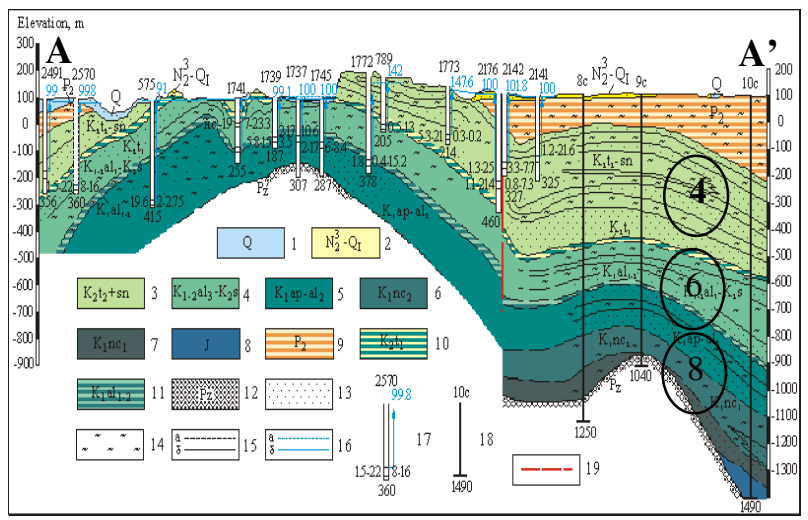

Fig. 3 Schematic figure of geo-hydrological profile by borehole data (A-A' cross section). 
In the study area the uppers layer was Quaternary period formed roughly $1.8 \mathrm{Ma}$ (million years ago) up to present, while the lowest layer was Jurassic period that extends from about $199.6 \pm 0.6 \mathrm{Ma}$ to $145.4 \pm 4.0 \mathrm{Ma}$.

The layer no. 4 , no. 6 and no. 8 were giving indicator as a good aquifer because of (1) the layer consist mostly sand litho-logical composition, (2) the content of water in the hydro-geological well.

\section{c) Specific Yield (Sy)}

Specific yield was expressed as a ratio of the volume of water that could be released from the volume of material containing the water. Specific yield was generally depending on the depth of aquifer. The shallower layer had larger value than the deeper layer. The specific yield (Table 1) was adopted from printed map provided by Veselov et al. ${ }^{1)}$. Then it was overlaid with the aquifer map (Fig. 2) to determine the location and value of specific yield.

\section{(2) Methodology}

The estimation of the groundwater storage and its distribution used GIS technique was outlined in Fig. 4.

\section{a) Georeferencing}

All of the available maps in this study did not have same coordinate system. Then all of them were imported and georeferenced with ArcMap.

Table 1 The specific yield value of each aquifer.

\begin{tabular}{|c|c|c|c|c|}
\hline \multirow[t]{2}{*}{ Aquifer } & \multicolumn{2}{|c|}{ Layer 4} & \multicolumn{2}{|c|}{ Layer $6 \& 8$} \\
\hline & Min Sy & Max Sy & Min Sy & Max Sy \\
\hline Central Kyzylkumskiy & \multicolumn{2}{|c|}{$1 \times 10^{-3}$} & \multicolumn{2}{|c|}{$1.3 \times 10^{-5}$} \\
\hline Priaralskiy & $1 \times 10^{-4}$ & $5.3 \times 10^{-3}$ & $1 \times 10^{-4}$ & $1.6 \times 10^{-3}$ \\
\hline North Kyzylkumskiy & $1 \times 10^{-3}$ & $6 \times 10^{-3}$ & $1.3 \times 10^{-5}$ & $7 \times 10^{-3}$ \\
\hline Arisskiy & \multicolumn{2}{|c|}{$1 \times 10^{-3}$} & \multicolumn{2}{|c|}{$1.3 \times 10^{-5}$} \\
\hline Bukharaskiy & \multicolumn{2}{|c|}{$1 \times 10^{-3}$} & \multicolumn{2}{|c|}{$1.3 \times 10^{-5}$} \\
\hline East Kyzylkumskiy & \multicolumn{2}{|c|}{$1 \times 10^{-3}$} & \multicolumn{2}{|c|}{$1.3 \times 10^{-5}$} \\
\hline Zeravshan & \multicolumn{2}{|c|}{$1 \times 10^{-3}$} & \multicolumn{2}{|c|}{$1.3 \times 10^{-5}$} \\
\hline Hill & \multicolumn{2}{|c|}{$1 \times 10^{-3}$} & \multicolumn{2}{|c|}{$1.3 \times 10^{-5}$} \\
\hline Bukantau & \multicolumn{2}{|c|}{$1 \times 10^{-3}$} & \multicolumn{2}{|c|}{$1.3 \times 10^{-5}$} \\
\hline
\end{tabular}

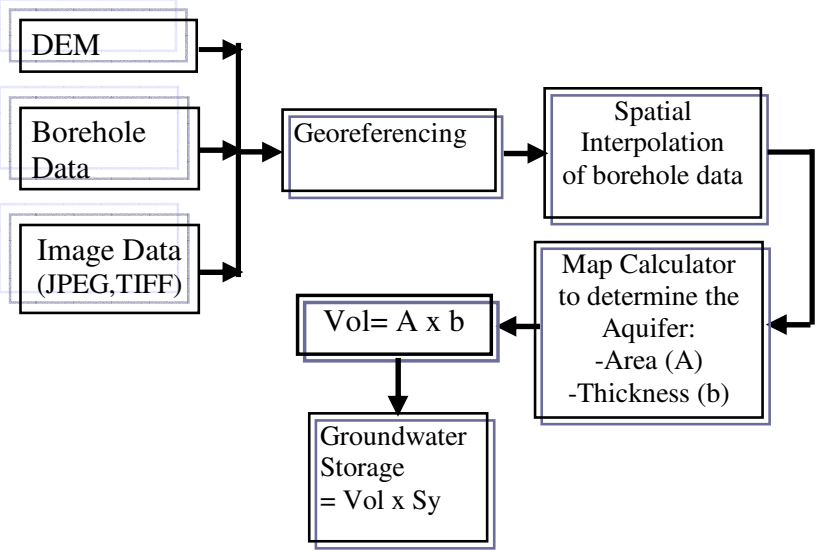

Fig.4 Flowchart of estimation of groundwater storage and its distribution.

\section{b) Spatial interpolation of borehole data}

Spatial interpolation was the procedure of estimating the value of properties at unsampled sites within the area covered by existing observations, in almost all cases the property must be interval or ratio scaled ${ }^{9)}$. After converted borehole data into point, then it was need to make grid (raster) data by spatial interpolation. The grid resolution was set 1 $\mathrm{km}^{2}$ as well as topography data from GTOPO30.

The spline method was selected to interpolate the depth of aquifer layer. The reason why the spline was that the small number of data points and the locations of the borehole were not well distributed 10)

\section{c) Map calculator to determine volume of groundwater}

After all the data were converted into raster data then the volume of groundwater storage could be calculated using map calculator.

\section{d) Groundwater storage}

Groundwater (GW) storage was defined as the volume of water that could be theoretically extracted if the aquifer were completely drained ${ }^{11)}$.

$$
G W \text { storage }=\text { Aquifer surface area } \times b \times S y
$$

where $b$ was saturated thickness of the aquifer (it was distance from the top of the water table to the top of the underlying bedrock) and $S y$ was the specific yield.

\section{RESULT AND DISCUSSION}

The groundwater storage was depending on three factors as the aquifer surface area, the saturated thickness of the aquifer, and the specific yield. The first parameter was based on topography map. The second and the third parameters were based on the interpretation of the geo-hydrology map.

The surface of some aquifer area was laid between Uzbekistan and Kazakhstan. Total of the aquifer surface area which belongs to Uzbekistan was summarized in Table 2.

The value of specific yield was varied between $1.3 \times 10^{-5}$ to $7 \times 10^{-3}$, and depending on the depth of aquifer as showed in Table 1.

\section{(1) Distribution of groundwater storage in Uzbekistan area}

In Table 2, the calculation result showed that the biggest of the groundwater storage was in the Priaralskiy aquifer then followed by the Central Kyzylkumskiy aquifer. The aquifer surface area and the specific yield of The Priaralskiy aquifer were 
higher than in The Central Kyzylkumskiy aquifer. However, the groundwater storage in The Bukharaskiy aquifer was bigger than The North Kyzylkumskiy aquifer even though the specific yield of The Bukharaskiy aquifer was smaller than The North Kyzylkumskiy aquifer. The surface aquifer area of The Bukharaskiy aquifer was also wider than The North Kyzylkumskiy aquifer. From these result, it was concluded that the groundwater storage was strongly affected by the surface aquifer area rather than by the specific yield.

\section{(2) Distribution of groundwater storage in whole area of aquifer}

The groundwater storage in a whole of area aquifer was lying on Uzbekistan and Kazakhstan. Table 2 showed that groundwater storage in The Priaralskiy was bigger than The North Kyzylkumskiy. Instead of the aquifer surface area, the saturated thickness aquifer of The Priaralskiy was also thicker than The North Kyzylkumskiy. The depth of saturated thickness of aquifer influenced the quantity of the groundwater storage also.

Similarly, it was closer with the argumentation of Veselov et al. ${ }^{1)}$, Kazakhstan's geologist who stated that the effective thickness of water bearing (saturated thickness of aquifer) deposition in Priaralskiy was $120 \mathrm{~m}-200 \mathrm{~m}$ while in North Kyzylkumskiy was $30 \mathrm{~m}-120 \mathrm{~m}$.

\section{(3) The most important of aquifer layer}

The groundwater storage in each layer was necessary to be estimated to control the groundwater extraction. From the calculation results, the most important aquifer layers, as main the groundwater storage in Uzbekistan, were layer no. 4, no.6 and no. 8.

The quantification of groundwater resources must be carefully carried out to identify the portion of the reserves that could be used without significantly diminishing surface runoff $^{12)}$. In example in Table 2, if the groundwater extraction of layer no. 4 reached the total volume of the existing groundwater storage, then it would be a warning to move or continue till layer number no. 6 or no. 8. It gave the information if we would extract the groundwater until aquifer layer no. 7, then the possibility to have water was low or even no water at all. Based on borehole data, the aquifer layer no. 7 was not good aquifer (aquiclude).

\section{(4) Groundwater storage per unit area}

The highest groundwater storage capacity per unit area (Fig.5) among six aquifers of Central Kyzylkumskiy, Bukharaskiy, East Kyzylkumskiy, Zeravshan, Hill and Bukantau were located in layer no.4. In Priaralskiy and North Kyzylkumskiy aquifers, it was located in layer no. 8.

It indicated that people who lived surrounding the six aquifer areas could easily use the shallow water. However, they had to extract the groundwater carefully. If the groundwater storage in aquifer layer no. 4 was ran out, it was difficult to continue till layer no.6 or no. 8. Those two layers did not have much groundwater storage.

In Priaralskiy and North Kyzylkumskiy aquifer, the people who lived in this area could use the shallow water also even the amount of groundwater storage were not so much. Here, It was possible to continue till layer no. 6 or no. 8 because those two layers above had enough amount of groundwater storage in these regions.

\section{(5) Prediction of GW extraction for drinking water}

The groundwater uses for drinking water was estimated based on the population data on $2005^{13)}$. The population growth rate was $2.5 \%$ per year ${ }^{14}$. The consumed water was assumed as 300 L/day/person. The demand of drinking water up to 50 years later was showed in Fig. 6.

Table 2 The groundwater storage and its distribution in each sub aquifer.

\begin{tabular}{|c|c|c|c|c|c|c|c|}
\hline & \multicolumn{2}{|c|}{ Aquifer surface area $*$ ) } & \multirow{2}{*}{$\begin{array}{l}\text { GW Storage in } \\
\text { Uzbekistan } * *)\end{array}$} & \multirow{2}{*}{$\begin{array}{l}\text { GW Storage in } \\
\text { Whole Area } * *)\end{array}$} & \multicolumn{3}{|c|}{ GW storage each layer (Uzbekistan) $* *$ ) } \\
\hline Sub Aquifer & Uzbekistan & A whole aquifer & & & Layer 4 & Layer 6 & Layer 8 \\
\hline Central Kyzylkumskiy & 42,217 & 42,217 & 2,676 & 2,676 & 2,608 & 9 & 59 \\
\hline Priaralskiy & 60,650 & 121,300 & 4,552 & 9,104 & 1,011 & 1,729 & 1,812 \\
\hline North Kyzylkumskiy & 32,367 & 107,889 & 2,450 & 8,165 & 662 & 316 & 1,473 \\
\hline Arisskiy & - & 23,686 & - & 1,348 & - & - & - \\
\hline Bukharaskiy & 38,644 & 38,644 & 2,465 & 2,465 & 2,405 & 5 & 54 \\
\hline East Kyzylkumskiy & 28,334 & 56,668 & 1,738 & 3,475 & 1,689 & 4 & 44 \\
\hline Zeravshan & 11,315 & 11,315 & 720 & 720 & 701 & 1 & 18 \\
\hline Hill & 9,643 & 9,643 & 620 & 620 & 602 & 3 & 15 \\
\hline Bukantau & 4,004 & 4,004 & 272 & 272 & 266 & 1 & 6 \\
\hline & & & 15,491 & 28,845 & & & \\
\hline
\end{tabular}

*) in $\mathrm{km}^{2}$.

**) in million $\mathrm{m}^{3}$. 


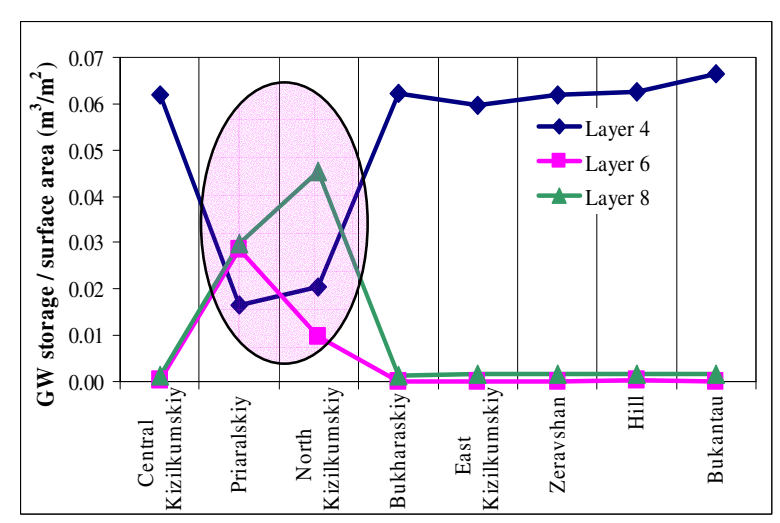

Fig. 5 Groundwater storage per unit area.

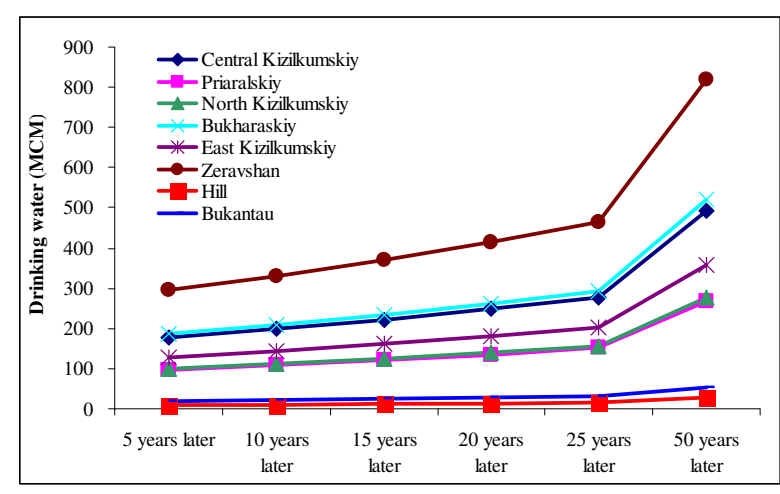

Fig. 6 The prediction of demand of drinking water up to 50 years.

Table 3 showed the groundwater storage from the drinking water abstraction with considering the lateral inflow. The lateral inflow (Table 3) which was estimated by Veselov et al. ${ }^{1)}$ was considered.

The groundwater storage in the Priaralskiy and Hill aquifers were sufficient to be extracted up to 50-years later. In North Kyzylkumskiy aquifer, the groundwater storage was able to used up to 25-years later. The critical areas were in Bukharaskiy and East Kyzylkumskiy aquifers. They were only possible to be extracted until 15-years later. The most critical was in Zeravshan aquifer which was only capable to provide water until 5-years later.
Those reasons above had to be considered into the groundwater extraction plan. Particularly, it should be emphasized on the critical aquifers. For example, in the Zeravshan, the limitation of groundwater exploitation should be determined. Otherwise optimizations of surface water become necessary.

\section{(6) Groundwater usage for cotton and wheat}

In the two aquifers, The Priaralskiy and The North Kyzylkumskiy, they were possible to use groundwater storage for cotton and wheat. Water demand for cotton during seasonal use was $1.05 \mathrm{~m}$ while for wheat was $0.65 \mathrm{~m}^{12)}$. If it was designed to grow up 1,000 ha each cotton and wheat then gross water need was $17 \mathrm{MCM}$ (million cubic meters). However, the quality of groundwater should be considered and it was beyond of this study.

\section{(7) Verification of the results}

The Central Asia Water Info (CAWATER Info ${ }^{5)}$ stated that the estimated groundwater reserve in Uzbekistan 18.5 BCM. In this study, it was found that groundwater storage in Uzbekistan was about 15.5 BCM. This differences was due to the area of this study did not cover Tashkent and Ferghana areas. They were located in the outside part of main of aquifer.

In Fig. 7, it showed that the result of the volume of groundwater storage in Uzbekistan area and a whole area of study.

In general, the result of this study was reliable to be compared with CAWATER Info result. The verification of the study was done based on the total of groundwater storage a whole area in Uzbekistan (except Tashkent and Ferghana) because in the CAWATER Info study, it was not explained in detail for each aquifer.

Table 3 The 50-years projection of groundwater usage.

\begin{tabular}{|c|c|c|c|c|c|c|c|c|c|}
\hline & \multicolumn{2}{|c|}{ Lateral Inflow (m/day) } & \multicolumn{7}{|c|}{ Groundwater storage (million $\mathrm{m}^{3}$ ) } \\
\hline & Layer 4 & Layer 6,8 & 2005 & $5 *)$ & $10 *)$ & $15 *)$ & $20 *)$ & $25 *)$ & $50 *)$ \\
\hline Central Kyzylkumskiy & 1 & 1 & 2,676 & 1,947 & 1,005 & -189 & $-1,677$ & $-2,766$ & $-8,207$ \\
\hline \begin{tabular}{|l} 
Priaralskiy \\
\end{tabular} & 3 & 1 & 4,552 & 4,513 & 4,358 & 4,067 & 3,614 & 3,379 & 2,207 \\
\hline North Kyzylkumskiy & 4.5 & 1 & 2,450 & 2,278 & 1,986 & 1,553 & 954 & 580 & $-1,290$ \\
\hline Bukharaskiy & 1 & 1 & 2,591 & 1,800 & 784 & -497 & $-2,090$ & $-3,260$ & $-9,112$ \\
\hline East Kyzylkumskiy & 1 & 1 & 1,738 & 1,197 & 501 & -378 & $-1,472$ & $-2,275$ & $-6,287$ \\
\hline Zeravshan & 1 & 1 & 720 & -711 & $-2,497$ & $-4,701$ & $-7,398$ & $-9,427$ & $-19,574$ \\
\hline Hill & 3 & 1 & 620 & 642 & 653 & 650 & 631 & 633 & 647 \\
\hline Bukantau & 1 & 1 & 272 & 190 & 85 & -48 & -213 & -334 & -941 \\
\hline
\end{tabular}

*) yrs later 


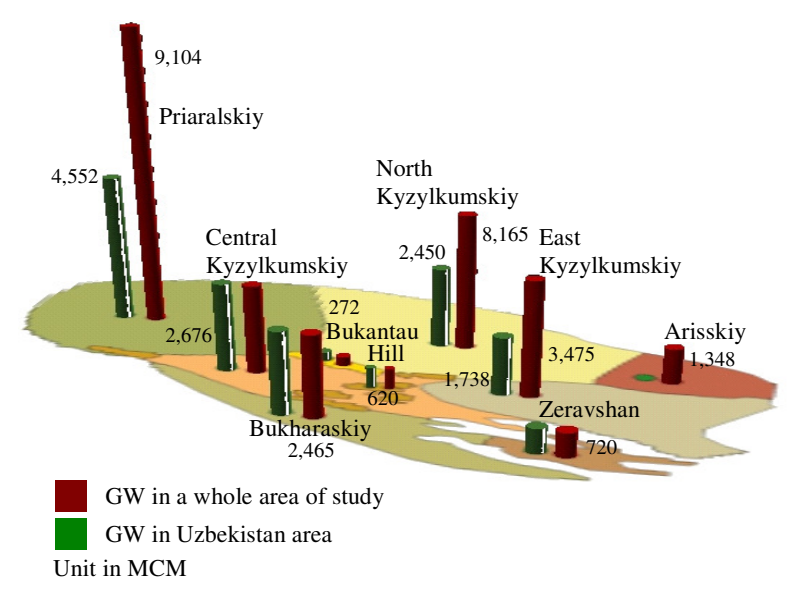

Fig.7 The distribution of groundwater storage in each sub aquifer.

\section{CONCLUSION}

From the results, the major finding of this study was summarized as below:

1. Since there were rare discussions or publication papers on the groundwater study on the arid area (Uzbekistan) in the global community, thus results on this study provided the open discussion and possibility of further studies on the groundwater related subjects.

2. The estimated groundwater storage in the Uzbekistan and surrounding aquifer area was determined by using GIS techniques and utilized the borehole data. In general the results were acceptable when it was compared with CAWATER Info results. The total groundwater storage in Uzbekistan was estimated about 15.5 BCM (billion cubic meter), while CAWATER Info gave 18.5 BCM.

3. The distribution of the groundwater storage was identified. The groundwater storage in Uzbekistan was mainly distributed on layer no. 4, 6 , and 8. Layer 4, 6 and 8 were confined aquifer, but in the some places layer no. 4 and no. 6 were unconfined aquifer. The groundwater storage in Kyzylkumskiy aquifer was about 6.8 BCM.

4. This distribution could give better understanding of the role of groundwater storage in the area of study and provided support data for the groundwater management.

5. From the estimation of groundwater extraction, it was still possible to use the groundwater storage for irrigation and drinking water in Priaralskiy and North Kyzylkumskiy aquifers.

6. Field survey and discussion results with the domestic researchers (ICARDA) have been done since August 2007. Basically, they were agree with the results and would support more data for further study.

ACKNOWLEDGMENT: The authors express sincere thanks to COE- $21^{\text {st }}$ Univ. of Yamanashi, SUNADA CREST of JST for supporting this study and Dr. Kristina Toderich (ICARDA, Uzbekistan) for the collaborative works.

\section{REFERENCES}

1) Veselov, V., Panichkin, V., Trushel, L., Zakharova, N., Kalmykova, N., Vinnikova, T. and Miroshnichkenko, O.: Eastern Priaralye, Institute of hydrogeology and hydrophysics of the Ministry of education and science of the Republic of Kazakhstan, 2005.

2) Takhirov, N., Radjabov, Sh. and Toleubaev, O.: The Substantiation and Development of Management Bases of Deep Underground Waters Stock in Aral Sea Region, Aral Sea Project, 2004.

3) Kharad, S.M., Srinivas Rao, K. and Rao, G.S.: GIS based Groundwater Assessment Model, 1999.

4) Zavialov, P.: Physical Oceanography of The Dying Aral Sea, page 56, Springer, Praxis Publishing, Chichester, UK, 2005.

5) Dukhovny, V. and Schutter, J.: Integrated Water Resources Management for Wetlands Restoration in the Aral Sea Basin Project, Central Asia Water Info- NATO Program, The monograph "South Priaralie: New Prospects”, Scientific-Information Center of ICWC, 2003.

6) ICARDA (International Center For Agriculture Research In The Dry Areas), Yamanashi University, ICBA (International Center For Bio-saline Agriculture) and IWMI (International Water Management Institute): Round Table Meeting on Strategies For Marginal Water/Land Use and Salinity Control in The Aydarkul-Arnasay Lakes System and Southwestern Kyzylkum Desert, August 2007.

7) Johnson, T.A. and Njuguna, W.M.: Aquifer Storage Calculation using GIS and MODFLOW, Los Angeles County, California, ESRI User Conference Proceedings, San Diego, USA, 2002.

8) Singh, A. Kr. and Prakash, S.R.: An Integrated Approach of Remote Sensing, Geophysics and GIS to Evaluation of Groundwater Potentiality of Ojhala Sub-watershed, Mirzapur District, U.P., India, Conference Paper, Asian Conference on GIS, GPS, Aerial Photography and Remote Sensing, Bangkok - Thailand, 2002.

9) http://www.geog.ubc.ca/courses/klink/gis.notes/ncgia/u40. html\#SEC40.1

10) http://www.csc.noaa.gov/benthic/mapping/analyzing/spatia $\underline{1 . h t m}$

11) Theodore, A. J. and Wanjiru M. N.: Aquifer Storage Calculations Using GIS and MODFLOW - Los Angeles County - California, ESRI User Conference Proceedings San Diego USA, July 2002.

12) Erie, L.J., O.F. French, D.A. Bucks and K. Harris: Consumptive Use of Water by Major Crops in the Southwestern United States, pages 6 and 18, USDA-ARS Conservation Research Report Number 29, 1981.

13) Uzbekistan Development Gateway, http://www.gateway. uzl.

14) Curtis, G.E.: Uzbekistan - A Country Study, Washington, GPO for the Library of Congress, 1996.

(Received September 30, 2007) 